\title{
PROFIL KEMAMPUAN KONEKSI MATEMATIS PESERTA DIDIK DALAM MENYELESAIKAN SOAL CERITA DITINJAU DARI KEMAMPUAN MATEMATIKA
}

\author{
Siti Julaeha ${ }^{1}$, Mustangin ${ }^{2}$, Abdul Halim Fathani ${ }^{3}$ \\ ${ }^{1,2,3}$ Program Studi Pendidikan Matematika FKIP Universitas Islam Malang \\ julaehas885@gmail.com,
}

\begin{abstract}
This study aims to describe the mathematical connection ability of students in completing the task of the story problem in terms of moderate math skills. This research uses a descriptive qualitative approach. The subject of this research is the students of grade VIII MTSN 1 Kota Pasuruan as much 2 students. Selection of research subjects according to his mathematical skills were learners are taken on the basis of teacher documents daily tests of material value woke room flat sides and discussions with math teacher class VIII. The results show that the mathematical connection skills of students with moderate mathematical abilities was able 2 of the 3 indicators of mathematical connection skills in completing the task of the story problem. Based on data, the AR subject turns out to have an average daily test of 75 which shows that they tend to have high math skills and tend not to be able to fulfill any indicators of mathematical connection skills in completing the task of the story problem, while the NL subject turns out to have an average daily test is 69 which indicates that there is a tendency towards low math skills.
\end{abstract}

Keywords: mathematical connection skills, task of the story problem, math skills.

\begin{abstract}
Abstrak
Penelitian ini bertujuan untuk mendeskripsikan kemampuan koneksi matematis peserta didik dalam menyelesaikan soal cerita ditinjau dari kemampuan matematika sedang. Penelitian ini menggunakan pendekatan kualitatif deskriptif. Subjek penelitian yakni peserta didik kelas VIII MTsN 1 Kota Pasuruan sebanyak 2 peserta didik. Pemilihan subjek penelitian berdasarkan kemampuan matematika sedang peserta didik yang diambil berdasarkan dokumen guru yaitu nilai ulangan harian materi bangun ruang sisi datar dan diskusi dengan guru pengampu mata pelajaran matematika kelas VIII. Berdasarkan analisis data diperoleh hasil penelitian bahwa kemampuan koneksi matematis peserta didik berkemampuan matematika sedang mampu memenuhi 2 dari 3 indikator kemampuan koneksi matematis dalam menyelesaikan soal cerita. Berdasarkan data subjek AR diketahui memiliki rata-rata nilai harian 75 yang menunjukkan bahwa cenderung kepada kemampuan matematika tinggi dan cenderung tidak dapat memenuhi satupun indikator kemampuan koneksi matematis dalam menyelesaikan soal cerita materi kubus dan balok, sedangkan subjek NL ternyata memiliki rata-rata nilai harian adalah 69 yang menunjukkan bahwa cenderung kepada kemampuan matematika rendah.
\end{abstract}

Kata kunci: kemampuan koneksi matematis, soal cerita, kemampuan matematika.

\section{PENDAHULUAN}

Pembelajaran matematika merupakan pembentukan pola pikir dalam memahami suatu pemahaman dan penalaran suatu hubungan antara makna-makna tersebut. Sesuai pendapat (Amir M.Z, 2015) menyatakan bahwa pembelajaran matematika adalah aktivitas belajar mengajar yang dirancang pendidik dalam mengembangkan kreatifitas berpikir peserta didik agar dapat meningkatkan kemampuan berpikir, serta untuk membangun pengetahuan baru yang merupakan bentuk usaha dalam meningkatkan penguasaan materi matematika". Pembelajaran matematika adalah proses memberikan pengalaman peserta didik melewati serangkaian kegiatan terencana sehingga peserta didik memperoleh kompetensi tentang bahan matematika yang dipelajari (Yayuk, 2019, p. 2). Pembelajran yang dimaksud disini adalah kegiatan pendidik untuk memberikan peserta didik pengalaman belajar sehingga mewujudkan kondisi belajar yang menyenangkan. Tujuan pembelajran matematika untuk 
menanamkan cara berfikir sistematis, logis, kritis, kreatif dan konsisten sehingga memiliki sikap gigih dan percaya diri.

Koneksi matematis secara umum adalah hubungan secara internal (dalam matematika) dan eksternal (luar matematika). Hubungan internal merupakan hubungan antara ide matematika dengan matematika baik yang sedang dipelajari atau matematika yang lain. Hubungan eksternal yaitu hubungan antar matematika dengan bidang keilmuan lain di luar matematika ataupun dalam kehidupan sehari-hari. (Dewi, 2013, p. 284) mengungkapkan bahwa kemampuan koneksi matematis adalah kemampuan menghubungkan konsep-konsep matematika antara konsep matematika itu sendiri dan mengaitkan konsep-konsep matematika dengan bidang lainnya (luar matematika). Oleh karena itu kemampuan koneksi matematis merupakan salah satu kemampuan yang penting dalam pembelajaran matematika masa sekarang. Selain untuk mewujudkan tujuan pembelajaran, peserta didik mampu dalam mengaitkan matematika dalam kehidupan sehari-hari. Menurut (Hendriana, 2017, p. 83) menjelaskan, "siswa sekolah menengah harus memiliki dan mengemkembangkan kemampuan matematis salah satunya yaitu koneksi matematis".

Kemampuan koneksi matematis memiliki indikator-indikator yang dapat dilihat sebagai acuan untuk menentukan kemampuan koneksi seorang peserta didik. Menurut (NCTM, 2000, p. 64) menjelaskan, "indikator-indikator koneksi matematis meliputi, 1) Mengenali dan menggunakan hubungan antar ide-ide matematika, 2) Memahami bagaimana ide-ide pada matematika saling berhubungan satu sama lain dan menghasilkan kesatuan yang utuh, 3) Mengenali dan menerapkan matematika kedalam konteks diluar matematika".

Sumarmo, Kusuma, Purniati, NCTM, dan Wahyudin dalam (Hendriana, 2017, p. 85) merangkum indikator kemampuan koneksi matematis sebagai berikut:

a) Mencari hubungan antar berbagai representasi konsep dan prosedur, serta memahami hubungan antar topik matematika

b) Memahami representasi ekuivalen konsep yang sama, mencari koneksi satu prosedur ke prosedur yang lain dalam representasi yang ekuivalen

c) Mencari hubungan berbagai representasi konsep dan prosedur

d) Menggunakan koneksi antar topik matematika, dan antara topik matematika dengan topik lain

e) Menggunakan matematika dalam bidang studi lain atau kehidupan sehari-hari.

Berdasarkan uraian di atas maka kemampuan koneksi matematis dalam penelitian digunakan indikator kemampuan koneksi matematis peserta didik kelas VIII adalah sebagai berikut: mencari hubungan berbagai representasi konsep dan prosedur, menilai keterkaitan antar topik matematika, yang mewakili aspek keterkaitan antara topik-topik dalam matematika dengan topic lain, dan menerapkan konsep matematika dalam keilmuan bidang lain atau dalam kehidupan sehari-hari. Kemampuan koneksi matematis peserta didik dapat dikembangkan melalui proses menyelesaikan masalah. Salah satu bentuk menyelesaikan masalah yaitu dalam menyelesaikan soal cerita. Pengembangan dalam soal cerita yakni soal-soal yang disusun dengan muatan koneksi matematis 
yang menggambarkan situasi dalam kehidupan sehari-hari yang mengharuskan peserta didik agar menuliskan langkah-langkah penyelesaian dengan sistematika yang baik.

Soal cerita merupakan bentuk pertanyaan yang disusun untuk membantu peserta didik mengaitkan topik-topik dalam matematika dalam kondisi dunia nyata. Soedjadi dalam (Wijaya, 2019, p. 2) mengemukakan bahwa langkah-langkah dalam menyelesaikan soal cerita adalah sebagai berikut:

1) Menangkap makna tiap kalimat dengan membaca soal dengan baik dan cermat,

2) membatasi dan menunjukkan yang diketahui, yang ditanyakan dan menghitung permasalahan dalam soal,

3) Membuat penyelesain model matematika dari soal menurut aturan matematika yang selanjutnya mendapat jawaban dari soal tersebut,

4) Memulihkan jawaban model ke jawaban soal asal.

Berdasarkan uraian di atas soal cerita yang digunakan dalam penelitian ini adalah soal cerita pada materi kubus dan balok yang berkaitan dengan kehidupan sehari-hari. Adapun langkah-langkah menyelesaikan soal cerita dalam penelitian ini adalah 1) Membaca soal dengan bak, 2) Menuliskan yang diketahui dan ditanya, 3) Membuat model matematika, 4) Melakukan perhitungan, dan 5) Menuliskan jawaban akhir dengan tepat.

Pada penelitian ini yang dimaksud kemampuan matematika merupakan kemampuan yang telah dimiliki peserta didik dalam mata pelajaran matematika. Kemampuan matematika siswa dapat dibedakan kedalam tiga ketegori: yaitu kemmapuan matematika tinggi, sedang dan rendah. Mengacu pada skala penilaian yang ditetapkan oleh (Ratumanan dan Laurens, 2011), tingkat kemampuan matematika peserta didik dikategorikan menjadi kemampuan rendah jika $0 \leq$ rata-rata $\leq 60$, dikategorikan kemampuan sedang jika $60<$ rata-rata $<80$, dikategorikan kemampuan tinggi jika $80 \leq$ rata-rata $\leq 100$.

\section{METODE}

Penelitian ini menggunakan pendekatan kualitatif dan jenis penelitian deskriptif. Pendekatan deskriptif kualitatif dipilih karena penelitian dilakukan berkaitan dengan fenomena-fenomena yang sedang terjadi dan berkenaan dengan kondisi masa sekarang. Kehadiran peneliti dalam penelitian kualitatif menjadi instrumen kunci yang berkedudukan menentukan fokus penelitian, mencari dan memisah-misahkan sumber data, melakukan pengumpulan data, pengolahan data, analisis data, dan menghasilkan kesimpulan. Adapun tes, pedoman wawancara, dan studi dokumentasi digunakan sebagai instrumen pendukung. Subjek penelitian adalah 2 peserta didik kelas VIII MTs Negeri 1 Kota Pasuruan yang dikategorikan kemampuan matematika sedang berdasarkan pada dokumen guru yakni nilai ulangan harian materi bangun ruang sisi datar dan berdiskusi dengan guru pamong matematika yaitu Drs Muhammad Syafi'i.

Prosedur pengumpulan data pada penelitian dimulai dari: (1) Subjek mengerjakan tes kemampuan koneksi matematis; (2) Hasil tes kemampuan koneksi matematis; (3) Melakukan 
wawancara mendalam (in-depth interview) berbasis tugas untuk mengklarifikasi dan mengeksplorasi koneksi matematis peserta didik dalam menyelesaikan soal; (4) Hasil wawancara; (5) Trianggulasi teknik untuk memeriksa kredibilitas data; (6) Tahap analisis data, yaitu mengolah data yang didapat dari proses penelitian sehingga dapat menjawab rumusan masalah yang ditentukan. Prosedur pengumpulan data ditunjukkan pada bagan alir berikut.

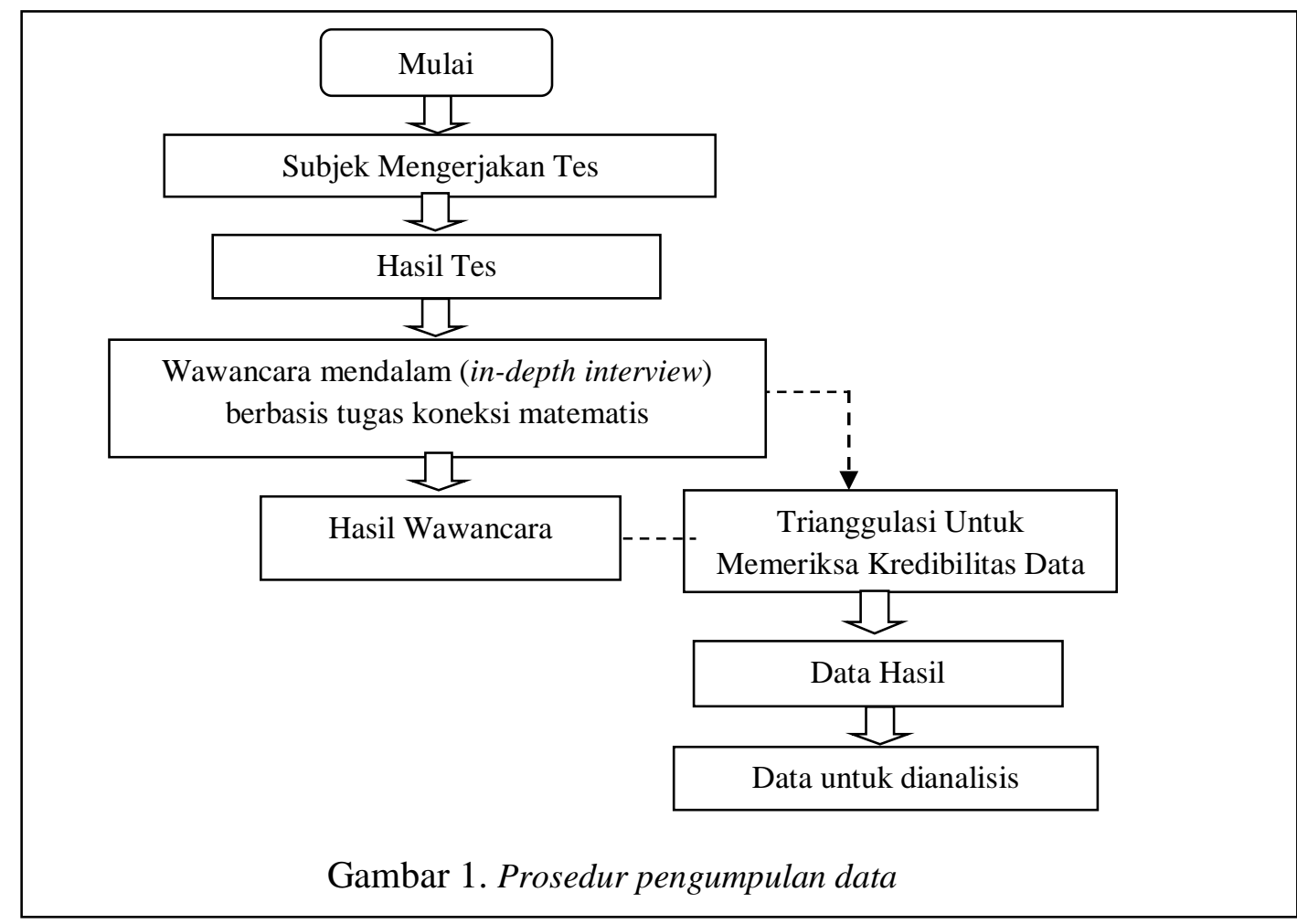

Analisis data penelitian ini menggunakan analisis data yang terbagi menjadi tiga tahap yaitu (1) Reduksi data, reduksi data pada penelitian ini terfokus pada jawaban tes dan hasil wawancara yang mengacu pada indikator-indikator kemampuan koneksi matematis peserta didik kelas VIII MTsN 1 Kota Pasuruan dengan memberikan coding terhadap nama peserta didik tersebut (2) penyajian data, Penyajian data yang dilaksanakan pada penelitian ini yaitu menyusuna jawaban tes dan hasil transkip wawancara secara sistematis dalam bentuk narasi yang dapat dipahami maknanya dari reduksi data yang kemudian dianalisis dan (3) conclusion drawing/verifying yaitu proses menarik kesimpulan dan verifikasi, Penarikan kesimpulan pada penelitian ini dilakukan dengan menilai pencapaian indikator kemampuan koneksi matematis peserta didik dalam menyelesaikan soal cerita.

\section{HASIL}

Mendeskripsi kemampuan koneksi matematis peserta didik dalam menyelesaikan soal cerita berkemmapuan matematika sedang adalah bertujuan dari penelitian ini. Teknik pengumplan data dalam penelitian ini menggunakan metode tes, wawancara, dan dokumentasi Sebelum tes dan wawancara digunakan terlebih dulu dilaksanakan proses validasi. Validasi dilaksanakan oleh dosen ahli yaitu dosen pendidikan matematika Universitas Islam Malang dan praktisi yaitu guru matematika 
MTsN 1 Kota Pasuruan. Subjek penelitian yakni AR dan NL. Subjek AR adalah peserta didik yang mempunyai nilai ulangan harian 75 dan subjek NL adalah peserta didik yang mempunyai nilai ulangan harian 69. Profil kemampuan koneksi matematis dalam menyelesaikan soal cerita subjek AR adalah sebagai berikut.

\section{Subjek AR}

Berdasarkan hasil tes yang telah dilakukan kepada subjek AR, sehingga didapatkan ringkasan data hasil tes kemampuan koneksi matematis yaitu.

Tabel 1.

Paparan Data Hasil Tes Subjek AR

\begin{tabular}{|l|l|l|}
\hline & $\begin{array}{l}\text { Indikator Kemampuan } \\
\text { Koneksi Matematis }\end{array}$ & Uraian \\
\hline A & $\begin{array}{l}\text { Menghubungkan antara } \\
\text { representasi konsep dan } \\
\text { prosedur }\end{array}$ & $\begin{array}{l}\text { Subjek AR mampu membuat model matematika pada soal sehingga } \\
\text { memahami konsep kubus dan balok pada soal dan rumus kubus dan balok } \\
\text { yang digunakan untuk mengerjakan soal. Namun pada soal nomor 2 } \\
\text { melakukan kesalahan perhitungan. }\end{array}$ \\
\hline B & $\begin{array}{l}\text { Menilai keterkaitan } \\
\text { antar topik matematika }\end{array}$ & $\begin{array}{l}\text { Subjek AR mampu melakukan perhitungan dengan mengaitkan antar topic- } \\
\text { topik matematika. }\end{array}$ \\
\hline C & $\begin{array}{l}\text { Menerapkan konsep } \\
\text { matematika dalam } \\
\text { bidang studi lain dan } \\
\text { kehidupan sehari-hari }\end{array}$ & $\begin{array}{l}\text { Subjek AR tidak mampu menentukan kertas kado yang dibutuhkan dan } \\
\text { uang yang harus disiapkan untuk membeli kertas kado, menentukan uang } \\
\text { yang harus disiapkan untuk membeli kawat, menentukan lama waktu } \\
\text { pengerjaan dan pukul berapa dapat menyelesaiakn pekerjaannya, mampu } \\
\text { menentukan model atau kalimat matematika sesuai soal yang diberikan dan } \\
\text { tidak mampu menuliskan jawaban akhir dengan benar. }\end{array}$ \\
\hline
\end{tabular}

Berdasarkan transkip wawancara yang telah dilakukan kepada Subjek AR, terkait dengan penggalian informasi sebagaimana yang diuraikan di atas, maka diperoleh ringkasan hasil wawancara kemampuan koneksi matematis, seperti pada Tabel 2.

Tabel 2. Paparan Data Wawancara Subjek AR

\begin{tabular}{|l|l|l|}
\hline & $\begin{array}{l}\text { Indikator Kemampuan } \\
\text { Koneksi Matematis }\end{array}$ & Uraian \\
\hline A & $\begin{array}{l}\text { Menghubungkan antara } \\
\text { representasi konsep dan } \\
\text { prosedur }\end{array}$ & $\begin{array}{l}\text { Subjek AR menyatakan bahwa mampu menyebutkan yang diketahui, } \\
\text { ditanya dan membuat model matematika pada soal sehingga } \\
\text { mengetahui konsep matematis pada soal dan rumus yang digunakan } \\
\text { untuk menyelesaikan pengerjaaan, namun masih ada kesalahan } \\
\text { perhitungan dalam mengerjakan pada nomor 2 }\end{array}$ \\
\hline B & $\begin{array}{l}\text { Menilai keterkaitan antar topik } \\
\text { matematika }\end{array}$ & $\begin{array}{l}\text { Subjek AR mampu menyatakan bahwa mampu melakukan } \\
\text { perhitungan dengan mengaitkan antar topik matematika }\end{array}$ \\
\hline C & $\begin{array}{l}\text { Menerapkan matematika } \\
\text { dalam bidang studi lain dan } \\
\text { kehidupan sehari-hari }\end{array}$ & $\begin{array}{l}\text { Subjek AR menyatakan bahwa belum mampu menentukan berapa } \\
\text { uang yang dibutuhkan, berapa lama waktu pengerjaan dan tidak dapat } \\
\text { menuliskan hasil akhir dengan tepat karena kekeliruan perhitungan } \\
\text { dalam mengerjakan }\end{array}$ \\
\hline
\end{tabular}

Berdasarkan hasil tes dan wawancara dapat diperoleh kesimpulan bahwa terdapat kesejajaran dan konsistensi data subjek AR, maupun berdasarkan hasil jawaban tes kemampuan koneksi 
matematis dan hasil wawancara. Berarti dalam hal ini data subjek AR kredibel (valid), sehingga dapat dianalisis untuk memperoleh jawaban pertanyaan penelitian.

Subjek AR dari hasil tes dan wawancara mampu membaca soal dengan baik serta menyatakan diketahui dan ditanya dari soal, membuat model matematika dan menentukan volume balok dan luas permukaan balok, menghitung keseluruhan panjang rusuk kubus dan balok, tetapi subjek AR melakukan kesalahan dalam perhitungan, dan menghitung lama pengecetan bak mandi dengan rumus luas permukaan kubus dan lama mengisi bak mandi dengan rumus volume kubus, selanjutnya subjek AR dalam wawancara mengetahui konsep unsur-unsur kubus dan balok dan mematuhi instruksi dalam soal yakni tidak boleh ada yang tertumpuk. Senada dengan pendapat Aspuri dan Heni (2019) menyatakan bahwa kemampuan koneksi matematis pada setiap indikator kemampuan koneksi peserta didik dalam menghubungkan konsep yaitu $60 \%$.

Subjek AR dari hasil tes dan wawancara tidak mampu memenuhi indikator menerapkan konsep matematika dalam bidang keilmuan lain dan kehidupan nyata, diketahui tidak mampu menentukan kertas kado yang dibutuhkan dan uang yang harus disiapkan, karena dalam perhitungan di atas subjek AR tidak teliti berimbas pada hasil akhir yang tidak tepat, selanjutnya dalam wawancara tidak dapat menyatakan uang yang harus disiapkan, tidak mampu menentukan total lama waktu pengecetan dan pengisian bak mandi dengan benar dan tidak dapat menentukan pukul berapa dapat menyelesaikan pekerjaannya.

Subjek AR dari hasil tes dan wawancara mampu memenuhi indikator menilai keterkaitan antar topik matematika diketahui mampu mengkonversikan volume kubus dengan satuan $\mathrm{cm}^{3}$ (luas) dalam satuan liter (volume).

Berdasarkan hasil analisis kemampuan koneksi matematis di atas diketahui indikator yang terpenuhi dari subjek AR ditampilkan pada Tabel 3.

Tabel 3.

Profil Kemampuan Koneksi Matematis Subjek AR

\begin{tabular}{|l|l|l|}
\hline $\begin{array}{l}\text { Indikator Kemampuan Koneksi } \\
\text { Matematis }\end{array}$ & $\begin{array}{l}\text { Langkah-Langkah dalam Menyelesaikan } \\
\text { Soal Cerita }\end{array}$ & $\begin{array}{l}\text { Keteranga } \\
\text { n }\end{array}$ \\
\hline $\begin{array}{l}\text { Menghubungkan representasi konsep } \\
\text { dengan prosedur }\end{array}$ & $\begin{array}{l}\text { - Membaca soal dengan baik } \\
\text { - Menuliskan yang dietahui dan ditanya } \\
\text { - Membuat model matematika }\end{array}$ & $\sqrt{ }$ \\
\hline Menilai keterkaitan antar topik matematika & - Melakukan perhitungan & $\sqrt{ }$ \\
\hline $\begin{array}{l}\text { Menerapkan konsep matematika dalam } \\
\text { bidang ekonomi dan kehidupan sehari-hari }\end{array}$ & • Menuliskan jawaban akhi dengan benar & $\mathrm{X}$ \\
\hline
\end{tabular}

Keterangan: $\quad \sqrt{ }=$ Terpenuhi

$$
\mathrm{X}=\text { Tidak Terpenuhi }
$$

Profil kemampuan koneksi matematis dalam menyelesaikan soal cerita subjek NL adalah sebagai berikut. 


\section{Subjek NL}

Berdasarkan hasil tes yang sudah dilakukan kepada Subjek NL, sehingga didapatkan ringkasan data hasil tes kemampuan koneksi matematis seperti pada Tabel 4.

\section{Tabel 4.}

Paparan Data Hasil Tes Subjek NL

\begin{tabular}{|l|l|l|}
\hline & $\begin{array}{l}\text { Indikator Kemampuan } \\
\text { Koneksi Matematis }\end{array}$ & Keterangan \\
\hline A & $\begin{array}{l}\text { Menghubungkan antara } \\
\text { representasi konsep dan } \\
\text { prosedur }\end{array}$ & $\begin{array}{l}\text { Subjek NL tidak mampu membuat model matematika pada soal karena } \\
\text { tidak memahami konsep kubus dan balok pada soal dan rumus kubus } \\
\text { dan balok yang digunakan untuk mengerjakan soal. }\end{array}$ \\
\hline B & $\begin{array}{l}\text { Menilai keterkaitan antar } \\
\text { topik matematika }\end{array}$ & $\begin{array}{l}\text { Subjek NL tidak mampu melakukan perhitungan dengan mengaitkan } \\
\text { antar topik matematika. }\end{array}$ \\
\hline C & $\begin{array}{l}\text { Menerapkan matematika } \\
\text { dalam bidang studi lain dan } \\
\text { kehidupan sehari-hari }\end{array}$ & $\begin{array}{l}\text { Subjek NL tidak mampu menentukan model atau kalimat matematika } \\
\text { sesuai soal yang diberikan dan menerapkan konsep kubus dan balok } \\
\text { dalam bidnag studi lain dan kehidupan sehari-hari dan tidak mampu } \\
\text { menuliskan jawaban akhir dengan benar. }\end{array}$ \\
\hline
\end{tabular}

Berdasarkan transkip wawancara yang telah dilakukan kepada Subjek NL, maka diperoleh ringkasan hasil wawancara kemampuan koneksi matematis, seperti pada Tabel 5.

Tabel 5. Paparan Data Wawancara Subjek NL

\begin{tabular}{|l|l|l|}
\hline & $\begin{array}{l}\text { Indikator Kemampuan } \\
\text { Koneksi Matematis }\end{array}$ & Keterangan \\
\hline A & $\begin{array}{l}\text { Menghubungkan antara } \\
\text { representasi konsep dan } \\
\text { prosedur }\end{array}$ & $\begin{array}{l}\text { Subjek NL menyatakan bahwa mampu menyebutkan yang diketahui } \\
\text { dan ditanya, namun tidak mampu membuat model matematika pada } \\
\text { soal nomor 2 dan 3 sehingga tidak mampu menyelesaikan } \\
\text { pengerjaaanya }\end{array}$ \\
\hline B & $\begin{array}{l}\text { Menilai keterkaitan antar topik } \\
\text { matematika }\end{array}$ & $\begin{array}{l}\text { Subjek NL tidak mampu menyatakan bahwa mampu melakukan } \\
\text { perhitungan dengan mengaitkan antar topik matematika }\end{array}$ \\
\hline C & $\begin{array}{l}\text { Menerapkan matematika } \\
\text { dalam bidang studi lain dan } \\
\text { kehidupan sehari-hari }\end{array}$ & $\begin{array}{l}\text { Subjek NL tidak mampu menyatakan kertas kado yang dibutuhkan, } \\
\text { uang yang harus disiapkan dan waktu yang dibutuhkan, sehingga } \\
\text { tidak dapat menuliskan jawaban akhir dengan benar. }\end{array}$ \\
\hline
\end{tabular}

Berdasarkan hasil tes dan wawancara dapat diperoleh kesimpulan bahwa terdapat kesejajaran dan konsistensi data subjek NL, maupun berdasarkan hasil jawaban tes kemampuan koneksi matematis dan hasil wawancara. Berarti dalam hal ini data subjek NL kredibel (valid), sehingga dapat dianalisis untuk memperoleh jawaban pertanyaan penelitian.

Subjek NL dari tes dan wawancara tidak mampu membaca soal dengan baik, menyebutkan yang diketahui dan ditanya pada soal, membuat model matematika dan melakukan perhitungan menentukan volume balok dengan tetapi tidak mampu menentukan luas permukaan balok dengan benar dan pada soal nomor 2 dan 3 hanya mampu menuliskan nomor soalnya saja sehingga tidak mampu memenuhi indikator koneksi matematis menghubungkan representasi konsep dengan prosedur.

Subjek NL dari tes dan wawancara tidak mampu memenuhi indikator menerapkan matematika dalam bidang ekonomi dan kehidupan sehari-hari dan menuliskan jawaban akhir dengan 
tepat, subjek NL tidak bisa menceritakan prosedur mengerjakan dan menerapkan dalam kehidupan sehari-hari.

Subjek NL dari tes dan wawancara tidak mampu menilai keterkaitan antar topic matematika, subjek NL tidak mampu menceritakan prosedur dalam mengerjakan soal nomor 3.

Berdasarkan hasil analisis kemampuan koneksi matematis di atas diketahui indikator yang terpenuhi dari subjek NL ditampilkan pada Tabel 6 sebagai berikut:

Tabel 6.

Profil Kemampuan Koneksi Matematis Subjek NL

\begin{tabular}{|l|l|l|}
\hline $\begin{array}{l}\text { Indikator Kemampuan Koneksi } \\
\text { Matematis }\end{array}$ & $\begin{array}{l}\text { Langkah-Langkah dalam Menyelesaikan Soal } \\
\text { Cerita }\end{array}$ & Keterangan \\
\hline $\begin{array}{l}\text { Menghubungkan representasi konsep } \\
\text { dengan prosedur }\end{array}$ & $\begin{array}{l}\text { - Membaca soal dengan baik } \\
\text { Menuliskan yang dietahui dan ditanya } \\
\text { Membuat model matematika }\end{array}$ & $\mathrm{X}$ \\
\hline $\begin{array}{l}\text { Menilai keterkaitan antar topik } \\
\text { matematika }\end{array}$ & $\bullet$ Melakukan perhitungan & $\mathrm{X}$ \\
\hline $\begin{array}{l}\text { Menerapkan matematika dalam bidang } \\
\text { ekonomi dan kehidupan sehari-hari }\end{array}$ & $\bullet$ Menuliskan jawaban akhi dengan benar & $\mathrm{X}$ \\
\hline
\end{tabular}

Keterangan: $\mathrm{X}=$ Tidak Terpenuhi

Subjek AR dan NL yang dikategorikan kemampuan matematika sedang. Diperoleh dari analisis hasil tes serta wawancara menunjukkan keduanya memiliki kemampuan yang berbeda. Subjek AR mampu memenuhi 2 dari 3 indikator kemampuan koneksi matematis dalam menyelesaikan soal cerita yang ditentukan dan subjek NL tidak mampu memenuhi satupun dari indikator kemampuan koneksi matematis dalam menyelesaikan soal cerita yang ditentukan.

Subjek AR mampu membaca soal secara benar dan menyatakan informasi diketahui dan ditanya dari soal, membuat model matematika dan melakukan perhitungan dengan menghubungkan representasi konsep dengan prosedur ketika mampu menghitung luas permukaan dan volume kubus dan balok. diperkuat dengan pendapat Kusuma, NCTM, Sumarmo, Wahyudin dan Purniati dirangkumkan secara lebih rinci dalam (Hendriana, 2017, p. 85) menyatakan bahwa "koneksi matematis individu tercapai salah satunya ketika dia dapat mencari hubungan antar berbagai representasi konsep dan prosedur". Menilai keterkaitan antar topik matematika ditunjukkan ketika mampu mengkonversikan satuan $\mathrm{cm}$ (luas) ke liter (volume). Sejalan dengan pernyataan (Isnaeni et al., 2018, p. 310) bahwa peserta didik memiliki kemampuan koneksi jika ia telah memenuhi salah satunya yaitu menghubungkan antara topik matematika dengan topik matematika yang lainnya. Subjek AR tidak dapat memenuhi indikator menerapkan matematika dalam bidang ekonomi dan kehidupan sehari-hari ditunjukkan ketika tidak mampu menentukan kertas kado yang dibutuhkan karena kesalahan dalam menghitung sehingga tidak mampu menentukan uang yang harus disiapkan dan tidak mampu menentukan pukul berapa dapat menyelesaikan pengerjaannya.

Subjek NL dari analisis hasil tes serta wawancara menunjukkan bahwa tidak mampu meneruskan pengerjaannya pada soal nomor 1 dan hanya menuliskan nomornya saja pada soal yang 
lain tanpa menuliskan jawabanya, jadi tidak memenuhi satupun indikator kemampuan koneksi matematis dalam menyelesaikan soal cerita yakni mampu membaca soal secara benar dan menyatakan informasi diketahui dan ditanya, membuat model matematika dan melaksanakan perhitungan dengan menghubungkan representasi konsep dengan prosedur. Menerapkan matematika dalam bidang ekonomi ditunjukkan ketika mampu menentukan uang yang harus disiapkan dan menerapkan matematika dalam kehidupan nyata, diperkuat dengan pendapat Kusuma, NCTM, Sumarmo, Wahyudin dan Purniati dirangkumkan secara lebih rinci dalam (Hendriana, 2017, p. 85) menyatakan bahwa "koneksi matematis individu tercapai salah satunya ketika dia dapat mneghubungkan antara representasi konsep dan prosedur dan dapat menggunakan matematika dalam bidang keilmuan lain atau kehidupan sehari-hari”. Menilai keterkaitan antara topik matematika, sejalan dengan pernyataan (Isnaeni et al., 2018, p. 310) bahwa peserta didik memiliki kemampuan koneksi jika ia telah memenuhi salah satunya yaitu mengaitkankan antara topik matematika dengan topik matematika lainnya.

Profil kemampuan koneksi matematis subjek dengan kemampuan matematis sedang dalam menyelesaikan soal cerita kubus dan balok dapat dilihat pada Tabel 7.

\section{Tabel 7}

Profil Kemampuan Koneksi Matematika Peserta Didik dengan Kemampuan Matematik Sedang dalam Menyelesaikan Soal Cerita

\begin{tabular}{|c|c|c|c|}
\hline \multirow[t]{2}{*}{$\begin{array}{l}\text { Langkah-Langkah Menyelesaikan } \\
\text { Soal Cerita }\end{array}$} & \multirow[t]{2}{*}{$\begin{array}{ll}\text { Indikator } & \text { Koneksi } \\
\text { Matematis } & \end{array}$} & \multicolumn{2}{|c|}{$\begin{array}{l}\text { Kemampuan Matematika } \\
\text { Sedang }\end{array}$} \\
\hline & & $\mathbf{A R}$ & NL \\
\hline $\begin{array}{l}\text { - Membaca soal dengan baik } \\
\text { - Menuliskan yang dietahui dan } \\
\text { ditanya } \\
\text { - Membuat model matematika }\end{array}$ & $\begin{array}{l}\text { Menghubungkan representasi } \\
\text { konsep dan prosedur }\end{array}$ & $\sqrt{ }$ & $\mathrm{X}$ \\
\hline - Melakukan perhitungan & $\begin{array}{l}\text { Menilai keterkaitan antar topik } \\
\text { matematika }\end{array}$ & $\sqrt{ }$ & $\mathrm{X}$ \\
\hline $\begin{array}{l}\text { - Menuliskan jawaban akhi dengan } \\
\text { benar }\end{array}$ & $\begin{array}{l}\text { Menerapkan matematika } \\
\text { dalam bidang ekonomi dan } \\
\text { kehidupan sehari-hari }\end{array}$ & $\mathrm{X}$ & $\mathrm{X}$ \\
\hline
\end{tabular}

Keterangan: $\sqrt{ }=$ Terpenuhi

$$
\mathrm{X}=\text { Tidak Terpenuhi }
$$

Pada Tabel Kemampuan koneksi matematis dalam menyelesaikan soal cerita peserta didik berkemampuan matematika sedang, subjek AR cenderung mampu memenuhi 2 dari 3 indikator koneksi matematis dalam menyelesaikan soal cerita dan subjek NL cenderung tidak mampu memenuhi semua indikator koneksi matematis dalam menyelesaikan soal cerita. Berdasarkan data subjek AR ternyata memiliki rata-rata ulangan pada materi barusida adalah 75 yang menunjukkan bahwa cenderung kepada kemampuan matematika tinggi, sedangkan subjek NL ternyata memiliki rata-rata ulangan pada materi barusida adalah 69 yang menunjukkan bahwa cenderung kepada kemampuan matematika rendah. Wawancara subjek AR diketahui mampu menguasai materi kubus 
dan balok, tetapi tidak teliti dalam menghitung dan tidak mampu memahami soal dengan baik, sedangkan subjek NL diketahui tidak menguasai materi kubus dan balok dan tidak mampu memahami soal sehingga kesulitan dalam mengerjakan soal. Senada dengan penelitian terdahulu (Umam, 2018) menyatakan bahwa peserta didik berkemampuan matematika sedang tidak mampu mengerjakan butir soal nomor 1 tetapi mampu terpenuhi indikator kemampuan koneksi matematis untuk soal nomor 2.

Hubungan kemampuan matematika dengan kemampuan koneksi matematis peserta didik dalam menyelesaikan soal cerita dapat digambarkan seperti halnya representasi hubungan seperti pada Gambar 2.

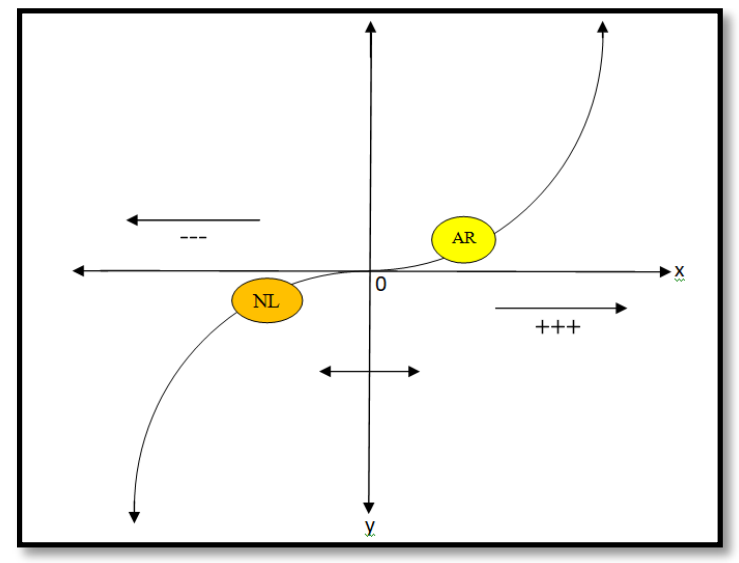

Gambar 2. Hubungan kemampuan koneksi matematis peserta didik dengan kemampuan matematika sedang dalam menyelesaikan soal cerita

Keterangan: $(--) \quad=$ Area kemampuan matematika rendah

$0 \quad=$ Kemampuan matematika sedang

$(+++)=$ Area kemampuan matematika tinggi

$\mathrm{x} \quad=$ Tingkat kemampuan matematika

$\mathrm{y} \quad=$ Tingkat kemampuan koneksi matematika

Sesuai dengan Gambar 1 Peserta didik berkemampuan matematika sedang cenderung dapat memenuhi indikator kemampuan koneksi matematis dan cenderung tidak dapat memenuhi indikator kemampuan koneksi matematis, ditunjukkan bahwa semakin tinggi tingkat kemampuan matematisnya maka semakin tinggi tingkat memenuhi indikator kemampuan koneksi matematisnya, dan jika semakin rendah tingkat kemampuan matematisnya maka semakin rendah tingkat dapat memenuhi indikator kemampuan koneksi matematisnya.

\section{KESIMPULAN}

Berdasarkan masalah dan tujuan penelitian yang dirumuskan, serta hasil analisis data kemampuan koneksi matematis peserta didik dengan kemampuan matematika sedang dalam menyelesaikan soal cerita kubus dan balok, maka dapat disimpukan bahwa Kemampuan koneksi matematis peserta didik berkemampuan matematika sedang cenderung dapat memenuhi indikator kemampuan koneksi matematis yaitu mampu memenuhi 2 dari 3 indikator kemampuan koneksi 
matematis dalam menyelesaikan soal cerita, berdasarkan data subjek AR ternyata memiliki rata-rata ulangan harian 75 yang menunjukkan bahwa cenderung kepada kemampuan matematika tinggi dan cenderung tidak dapat memenuhi satupun indikator kemampuan koneksi matematis dalam menyelesaikan soal cerita materi kubus dan balok, sedangkan subjek NL ternyata memiliki rata-rata ulangan harian adalah 69 yang menunjukkan bahwa cenderung kepada kemampuan matematika rendah.

Berdasarkan simpulan tersebut, maka saran yang dapat peneliti sampaikan adalah (1) Guru diharapkan lebih membimbing dan membiasakan peserta didik dengan memberikan soal-soal cerita kontekstual dalam kehidupan sehari-hari untuk meningkatkan dan menumbuhkan kemampuan koneksi matematis, (2) Peserta didik diharapkan membiasakan mengerjakan soal-soal cerita matematika sehingga kemampuan koneksi matematis peserta didik meningkat, (3) Peneliti lainnya diharapkan melakukan penelitian berkelanjutan mengenai penelitian eksperimen yang tepat untuk meningkatkan dan mengembangkan kemampuan koneksi matematis peserta didik dalam menyelesaikan soal cerita.

\section{DAFTAR RUJUKAN}

Amir M.Z, Z. (2015). Pembelajaran Matematika Menggunakan. http://repository.uinsuska.ac.id/10388/1/Psikologi Pembelajaran Matematika.pdf

Dewi, N. R. (2013). Peningkatan Kemampuan Koneksi Matematis Mahasiswa Melalui Brain-Based Learning Berbantuan Web. Prosiding SNMPM Univertas Sebelas Maret 2013, 1, 284.

Hendriana. (2017). Hard Skills dan Soft Skills Matematik Peserta Didik. Bandung: PT. Refika Aditama.

Isnaeni, S., Ansori, A., Akbar, P., \& Bernard, M. (2018). Analisis Kemampuan Koneksi Matematis Siswa SMP Pada Materi Persamaan dan Pertidaksamaan Lineas Satu Variabel. Journal On Education, 01(02), 309-316.

NCTM. (2000). Principles and Standards for School Mathematics. United States of America: The National Council of Teachers of Mathematics, Inc.

Ratumanan dan Laurens. (2011). Penilaian Hasil Belajar pada Tingkat Satuan Pendidikan. Surabaya: Unesa University Press.

Umam, K. (2018). Analisis Kemampuan Koneksi Matematis Materi Kubus dan Balok Berdasarkan Level Kognitif Peserta Didik Kelas VIII H SMPN 2 Gondang Tulungagung Tahun Ajaran 2017/2018. Program Sarjana IAIN Tulungagung.

Wijaya, A. arya dan M. (2019). Analsis Kesalahan Siswa Dalam Menyelesaikan Soal Cerita Pada Materi Sistem Linear Dua Variabel. MATHEdunesa, 8(2).

Yayuk, E. (2019). Pembelajaran Matematika Sekolah Dasar (SD). Malang: Universitas Muhammadiyah Malang. 